International Journal of Linguistics, Literature and Culture
Available online at https://sloap.org/journals/index.php/ijllc/
Vol. 6, No. 4, July 2020, pages: 16-26
ISSN: 2455-8028
https://doi.org/10.21744/ijllc.v6n4.902

\title{
Gender Discourse Analysis in Ursula K. Le Guin's Earthsea Series and its Turkish Translation
}

Deniz Özgün a

Article history:

Submitted: 18 April 2020

Accepted: 09 May 2020

\section{Keywords:}

critical discourse analysis;

Earthsea series;

gender discourse analysis;

linguistic and cultural gender;

Ursula K. Le Guin;

\begin{abstract}
This study aims to analyze the Earthsea Series, written by Ursula K. Le Guin, regarding how language is used by the author and its transference in Turkish translation in terms of cultural and linguistic elements of gender. Since the series was written in 23 years, they might, within themselves, indicate a considerable amount of differences in language used. Therefore, the translation of the series might adapt those differences following the target culture's transformation in that time shift. The source text and the target text are both examined with the Critical (Gender) Discourse Analysis approach concerning linguistic and cultural gender. The target text is also analyzed through source text adaptation in Turkish translation as well as female translation strategies. The fact that there are significant differences not only in languages of the source text and the target text but also in their cultures. Thus, this study demonstrates those significant differences in the source text and their transference in Turkish translation.
\end{abstract}

International journal of linguistics, literature and culture (c) 2020.

This is an open access article under the CC BY-NC-ND license.

Peer-review under responsibility of International Association for

Technology, Education and Language Studies (IATELS) (https://creativecommons.org/licenses/by-nc-nd/4.0/).

\section{Corresponding author:}

Deniz Özgün,

Translation Department, Cultural Translation Studies

Hacı Bayram Veli University, Ankara (HBVA), Turkey.

Email address: denizozgunn@gmail.com

a Translation Department, Cultural Translation Studies, Hacı Bayram Veli University, Ankara (HBVA), Turkey 


\section{Introduction}

The first wave of feminist movements which is also known as women's liberation movements started in the late 19th century and have accelerated during the first half of the 20th century in the United States. Women were seeking equal rights and they were not going to stop until they got these rights. Even though women sought equality in arts and literature, it was not seemed to be accomplished with ease. In men, dominated societies, women's writing has been seen as inferior until the second wave of the feminist movement which peaked in the 1960s and 1970s. After World War II, thanks to technological improvements, women's lives have changed significantly in developed countries. Due to the growth in the service sector, lots of women found jobs that didn't require physical power.

By the help of feminist movements, female translation gained momentum during the post-war period, after many protest movements have been demonstrated in Western Europe and North America. Even though in 1949, Simon de Beauvoir wrote "on ne nait pas femme, on le deviant" translated by E.M. Parshley as "one is not born, but rather becomes a woman" which were existed almost two decades ago, female writers and theorists referred to these works towards 1970. Biological sexual difference was extended because the new concept of gender came to surface trough Beauvoir's work and Parshley's translation. Scholars developed and practiced other means and analytical predicaments to comprehend these contradictions. According to Beauvoir's suggestion, "a baby born with female reproductive organs does not simply grow up to be a woman. She has to turn herself into a woman or more correctly". Then culture involved in these discrepancies and the term gender was associated with the fruit of social process which has to do a lot with the female her later life. (Flotow, 1997). In the 1980s, culture was regarded as a significant dimension to translation. Preoccupying questions like "how should we translate, what is a correct translation?" have been changed into questions that have more focus on a descriptive approach like "what do translations do, how do they circulate in the world and elicit a response?" (Simon, 1996). As a result of adopting the term culture in Translation Studies, scholars and theorists came up with new ideas, theories, and approaches.

Gender, as in other fields, always plays an important role in Translation Studies. Between 1750-1830 gender system in European translation underwent an important series of transformations. First, women aimed to change linguistic and cultural gender issues which are still ongoing debates amongst scholars. Today and in the last quarter of the 20th century, it is also possible to talk about Feminist Translation Studies having some strict differences from the earlier male-dominated translation for which female writing, translation, and other pieces of artwork have been seen inferior for centuries. Feminist translators have certainly been rebelling against patriarchal and sexist language both in society and translation since the first wave of the feminist movement started, therefore, they consciously manipulate the language itself while translating.

In the late 20th century female and especially feminist writing gain momentum in the USA and Western Europe. One of the well-known American feminist writers is Ursula Kroeber Le Guin who was born on October 21, 1929, in Berkeley, California, United States. She was a well-known American sci-fiction and high fantasy works writer who grew up with four brothers. She had an intellectual family but in her early works, she confronted some publishing problems. Her best-known published books are City of Illusions, The Left Hand of Darkness, and the Earthsea Series. However, thanks to her early novels such as Rocannon's World, Planet of Exile, and City of Illusions Le Guin gained the title of sci-fiction writer who has also written essays on feminist issues. Her worldly known fantasy book Earthsea Series which was written for children but later on it also attracted a broad adult readership. There are almost 23 years between her first book of the series A Wizard of Earthsea written in 1968 and the last book The Other Wind written in 2001. She died on January 22, 2018, in Portland, United States (Britanica, 2018).

\section{Literature review}

'Discourse' had its traditional meaning until the last part of the twentieth century: the intended meaning of a specific subject in writing or speech and writers such as Descartes and Machiavelli were linked to this practice. The term has been used with increasing frequency and new meanings in recent decades, reflecting the effect on the critical vocabulary of work done within and across the boundaries of different disciplines of discourse: linguistics, philosophy, literary criticism, history, psychoanalysis, and sociology. The term is now the meeting ground for various inquiries within the nature and use of language (Peter Childs, The Routledge Dictionary of Literary Terms, 2006).

According to Foucault's (Grace, 2002) concept of discourse(s), the term(s) is held as bodies of knowledge. His concept moves away from the linguistics and grammatical notions to the concept of discipline. Discipline used in

Özgün, D. (2020). Gender discourse analysis in Ursula K. Le Guin's Earthsea series and its Turkish translation. International Journal of Linguistics, Literature and Culture, 6(4), 16-26. https://doi.org/10.21744/ijllc.v6n4.902 
two perceptions refers to scholarly disciplines (such as science, medicine, psychiatry, sociology, etc.) and disciplinary institutions of social control to illustrate; schools, prisons, hospitals, and so on. Foucault's idea of discourse historically demonstrates the particular relations between discipline and disciplinary institutions. Foucault's concept of discourse has been taken into account in many different theories and disciplines.

Fairclough (2003) sees "discourses as ways of representing aspects of the world - the processes, relations, and structures of the material world, the 'mental world' of thoughts, feelings, beliefs and so forth, and the social world" and associates different discourses with different perspectives on the world due to different background and relations of people which affect the ways we understand and comprehend the discourses. Representation of discourses includes not only the actual world where we live but also imaginary, projective, and possible worlds.

The relationships between different discourses are one element of the relationships between different people — they may complement one another, compete with one another, one can dominate others, and so forth. Discourses constitute part of the resources which people deploy in relating to one another - keeping separate from one another, cooperating, competing, dominating - and in seeking to change how they relate to one another (Fairclough, 2003).

There is no widely accepted definition for discourse analysis, but we may talk about two mainstream remarks which are approved by many scholars and theorists. On the one hand, discourse is defined as examining the patterns of a language in the unit or units of a text which can be a phrase or utterance, on the other hand, it is the analyses of the patterns of a language across the texts as a whole unit, in other words, it focuses on context. There are also many other different points of views on discourse or discourses and its definition, but they somehow refer to the same frame.

Feminist Critical Discourse Analysis (CDA) developed in the last decades under several branches of discourse analysis and the notion of feminist is explicitly used by feminist scholars studying in these fields (Lazar, 2005). As in this area, it is possible to talk about other feminist branched areas such as; 'feminist stylistics' (Mills, 1995), 'feminist pragmatics' (Christie, 2000), and 'feminist conversation analysis' (Kitzinger, 2000). In all these fields, the very objective of the feminist scholars is to challenge with gender-related bias and male-centered world. Cameron wrote and clearly explained in 1992 that one of her most important goals was to "question the whole scholarly objective bias of linguistics and to show how assumptions and practices of linguistics are implicated in patriarchal ideology and oppression" (1992: 16). According to Spender (1981) the feminist scholars have also striven and criticized male dominancy across other disciplines, to illustrate; disciplines in humanities, social sciences, and sciences.

The vagueness in defining discourse emerges in feminist CDA as well. The question of whether to analyze the linguistic components of a text i.e. even an utterance may have a discourse(s) in itself or to analyze the text as a whole unite i.e. not analyzing the small unites like words or utterance but dealing with it holistically. Jørgensen and Phillips (2004), however, emphasize that texts cannot be analyzed discursively through its linguistic components, in other words, grammatical structures or unites, there has to be also social and cultural analysis of the texts. Therefore; beside linguistic analysis, texts also need social and cultural considerations to analyze concerning discourse. Jørgensen and Phillips stated that feminist CDA aims to reveal the ties between language use and social practice (2004: 66). "The focus is on the role of discursive practices in the maintenance of the social order and social change". Extensively, CDA is a social-constructivist approach which carries that representation of world are somewhat linguistic-discursive, implications are generally and socially explicit and information is made through social collaboration while social development of knowledge has social results. Since some scholars like Faiclough, Wodak (1997) and van Dijk (1994), instead of narrowing the social inequality to gender, preferred coping with all forms of social inequality and injustice, they are not labeled as explicit feminist critical discourse analysts (Lazar, 2005). There are several reasons why there is a need for explicit feminist CDA and in the following paragraphs, three major reasons will be discussed.

Why is Feminist Critical Discourse Analysis needed? First and one of the most important reasons is that even though critical discourse practitioners adopt a feminist critical perspective and analyze texts accordingly, they avoid using the word feminist explicitly. Lazar (2005) criticizes them for not working collectively and contributing feminist perspectives in the academic world. Secondly, there are CDA analysts who are thought to be feminist as Cameron (1998) who stated that all the pioneers and important figures in feminist CDA are white men from the USA and Europe and this statement was given credit and also particularly used by Wilkinson and Kitzinger (1995). However, on the contrary of this thought, it is possible to say that there are also women, in different geographical locations, contributing feminist research in CDA (Lazar, 2005). As mentioned in the previous paragraphs that in their works, Chouliaraki and Fairclough (1999) include and draw upon feminist research among other sources but citing feminist works is not an adequate effort in feminist CDA and there must be more than this. Thus, a distinctive 
feminist view is required within CDA. Thirdly, feminist scholars do not work as a unit because they are dispersed around the world. To have significance in CDA as the feminist branch they need to work collectively.

Originally discourse analysis has flourished in applied linguistics since the 1970s and two decades later, its practice was seen significant by the scholars of translation studies and used in the functionalist theories of translation targeting the analysis of text types, language function, the impact of translation and the participants of the translation event (Munday, 2001). Translation of choices within the textual metafiction, which has taken special attention from the scholars of translation studies with special focus on the function of Theme and its effect on the thematic development in the text, is one of the most essential topics in discourse analysis. Several types of research have been done considering this new insight into translation studies. Thanks to the development of this field, discourse analysis that had previously been substantially neglected have become prominent in translation studies (House, 2015). In translation studies, discourse analysis was applied through Halliday's register analysis model focused on both the source text and target text by analyzing the pragmatic functions of linguistic elements.

According to Halliday who built the bridge between CDA and TS with his works, such as the three features of the context of the situation, register analysis and systemic functional linguistics (grammar) which were mainly used in early CDA oriented TS studies and current studies, sees language as an event of communication and identifies three stages of functional meaning as ideational, intertextual and interpersonal meaning. Here the interpersonal meaning is the language used to constitute the relationship between the text producer and text receiver and while analyzing the interpersonal meaning, power is one of the fundamental types of relationship (M. A. K. Halliday, 1989).

Although CDA primarily means analyzing one text i.e. one language and one culture at a time, in TS objecting to analyze CDA in both the source text and the target text which is to say two languages and two cultures at a time. To analyze ST and TT in terms of CDA, both ST and TT have to be seen as a social, cultural, and political activity and combined these three acts. Most of the studies have been carried out in TS by using CDA concentrate on translation as social action and try to answer these questions; who is translating for whom, what is being translated, when is it being translated and what are the effects on the receiving culture? (Schaffner, 2002). Depending on the choices of translators, CDA has optional status in translation studies and is generally practiced as a supportive means in the current methodological approaches to provide an understandable reflection on language and culture of the texts both ST and TT. Mostly in the translation strategy, CDA has become a practical instrument to make decisions of the ST and TT context concerning cultural and social differences between the source language and target language societies. Furthermore, CDA assists translators to be aware of the cognitive process of translation and their contribution to the interpretation of the ST as well as understanding the meaning in the ST text that has not been overtly identified in translation studies (Valdeon, 2007).

Since the texts and discourses are the products of the human activity for communication in socio-cultural settings which is prevalent in CDA and TS, translators are not just a kind of mediators rendering a language into other languages, but, they rather produce new texts with the boundaries and limitations of their knowledge of linguistic, social and cultural background in the source texts and the target texts (Hatim \& Mason, 1990). Depending on the socio-cultural context of the source texts, translations are seen as target texts with a new socio-cultural context. Therefore, translators convey information by translation or interpreting the source text into the target text with some inevitable changes which are indispensable for a target text to be understood by the audiences of the target text and as a result of that CDA is needed both in the source text and the target text (Schäffner, 2004).

\section{Materials and Methods}

This study aims to analyze feminist discourse in Le Guin's Earthsea Series and its transference into the Turkish language. There are six connected novels in the series which have thirty-three years of the time difference between the first book written in 1968 and the last one written in 2001. However, in study three of the novels are subjected regarding years when there were written. Therefore, the first book A Wizard of Earthsea 1968, the fourth one Tehanu 1990, and the last book of the series The Other Wind 2001 were chosen to analyze. The reason behind the selection of the novels is the impact of feminist movements in literature in which though there have been several insufficient feminist attempts for centuries, they could not gain momentum until the late 1970s. (Simon, 2005), (Flotow, 1997), (Jouve, 1991), (Camus, Gastro, and Camus, 2017), (Leonardi, 2013), and (Godard, 1990). Thus, it is unlikely to see dominant feminist writing and discourse in the first book of Earthsea Series while the fourth and the last book might have examples of feminist perspective and deconstruction.

Özgün, D. (2020). Gender discourse analysis in Ursula K. Le Guin's Earthsea series and its Turkish translation. International Journal of Linguistics, Literature and Culture, 6(4), 16-26. https://doi.org/10.21744/ijllc.v6n4.902 
In this research, data is gathered concerning how feminist and non-feminist language is used in these three novels as well as their Turkish translations. Two different approaches such as Norman Fairclough Dimension of Critical Discourse Analysis and M. A. K. Halliday's Tripartite Division of Discourse is applied to analyze data. First, the fact that language has the power to challenge and change perceptions and it has been tooled by feminist writers and scholars to claim their existence in literature and translation, Fairclough's CDA has become a broad and primary discourse analysis approach in the academic field. Mainly in the analysis of the source text and the target text, the Fairclough CDA approach is adopted. In this interdisciplinary approach of CDA, Fairclough sees the language as a form of social practice, and any case of language is assumed as a communicative event. He has developed a model called dimensions which, in short, consists of three categories, such as text, discursive practice, and social practice. The first-dimension text can be speech, writing, and images or a mixture of all three forms of communication and it is called an analysis at the word level. The second-dimension discursive practice comprises the production of texts or the constitution of texts and in this dimension, the analysis takes place in the next level. The last dimension of social practice is about standards of society or the organizations in effect social structures and here the analysis is made at the norm level. The second approach is the Hallidayan Tripartite Division of Discourse applied to analyze conversations selected in the source texts and the target texts. According to Halliday, discourse analysis is based on the "systemic functional grammar" seeing the language as communication and suggesting that meaning is hidden in what the writer intentionally chooses, and these deliberate systematic choices should be analyzed regarding social and cultural perspective. Moreover, Halliday borrowed and advanced Bührer's three divisions of language functions which are field, tenor, and mode of discourse. In conversation analysis, in sum, the field is the actions taking place, the tenor is the participants and mode is the language use.

Translation of a literary work, such as drama, poem, novel, novella, etc. requires not only adequate linguistic knowledge in both source and target language but also cultural awareness of both languages. In general, there are two types of translators while dealing with a literary text, the first group strictly attached to the source text and save its structure at the cost of losing meaningful equivalence or the manipulating the message in its transference, while the second group somehow detached from the source text and rewrite or interpret what is given to them. Thus, this study researches feminist, non-feminist, and anti-feminist perspectives in ST as well as its transference to Turkish. Whether the translator adapts the feminist point of view or transfers the ST equally through literal translation is subjected.

The fact that this study is a descriptive one, the TT is examined through Gideon Toury's poly systems theory to assess its equivalence with the ST. First of all, Itamar Even-Zohar (1978), borrowing from the Russian Formalist of 1920, has studied poly systems that deal with literature not as a single part or unit but as a combination of other branches such as social, cultural, literary and historical framework. According to Even-Zohar, literature is the parts of social and cultural study fields and he believed it must be studied through these other related branches. Later on, Gideon Toury was affected by Even-Zohar's poly systems theory and developed it as a descriptive study in translation. In that new concept of study in translation as its name suggests, Toury describes what a translator is or what $\mathrm{s} /$ he does and made a description upon translators instead of giving a prescription about what s/he should be, or s/he should do. According to Toury, all target texts, which have similarities with the source texts, are in equivalence with the start texts and this relation of equivalence helps translators to find their path in translating initial norms. However, this equivalence is unique, and it changes from translator to translator because each translator employs different equivalence measurements between the source and the target texts. Thus, a literary work can be translated considering both Even-Zohan's poly systems theory and Toury's more sophisticated descriptive translation theory.

A gender study cannot be done without grasping feminism. Besides applying CDA, CA, and Toury's poly systems theory, since the study is conducted to analyze ST and TT concerning linguistic and cultural gender in language, feminist post-structuralist discourse analysis (FPDA) is used to analyze the findings. FPDA differs from $\mathrm{CDA}$ and $\mathrm{CA}$ in terms of using feminist etiquette and analyzing the language through a feminist perspective. FPDA is "a feminist approach to analyzing how speakers negotiate their identities, relationships and positions in their world according to how they are located by competing for yet interwoven discourses" (Baxter, 2003, p.1). As feminist movements have taken place during the last century, FPDA also challenges conventional patriarchy in which women and women's works are seen as inferior to men and their works.

The main sources of this study are the original version of Earthsea Series written by Ursula K. Le Guin which contains six separate books such as A Wizard of Earthsea (1968), The Tombs of Atuan (1971), The Farthest Shore (1972), Tehanu (1990), Tales from Earthsea (2001), and The Other Wind (2001) published by Saga Press. However, only three of these books such as; A Wizard of Earthsea, The Farthest Shore, and The Other Wind will be examined concerning linguistic and cultural gender. Besides, the Turkish translation the series translated by Çiğdem Erkal as 
Yerdeniz Öyküleri contains six books which are Yerdeniz Büyücüsü (2017), Atuan Mezarları (2017), En Uzak Sahil (2017), Tehanu (2017), Yerdeniz Öyküleri (2017), and Öteki Rüzgar (2018) published by Metis Yayınları. As in the ST, in translation also three of these books as the first one, the second one the last one will be analyzed.

\section{Results and Discussions}

\section{Quote 1: A Wizard of Earthsea}

\section{ST 1:}

The name he bore as a child, Duny, was given him by his mother, and that and his life were all she could give him, for she died before he was a year old. His father, the bronzesmith of the village, was a grim unspeaking man, and since Duny's six brothers were older than he by many years and went one by one from home to farm the land or sail the sea or work as a smith in other towns of the Northward Vale, there was no one to bring the child up in tenderness (p.1)

The child was named by his mother which on the one hand shows that the mother has the right to name her children. On the other hand, it is understood that the child's father is an unspeaking man, therefore; the mother takes her husband's responsibility for naming his children. There is the cultural stereotype of gender roles that imposes some conventional and also universal commitments upon both men and women. As in the passage taken from the first book, men have the duty of making a living, and women stay at home and raise children.

Men are known for their lack of affection not only in literature but also in the real world while women, in general, show their compassion towards their children and husbands. It is possible to talk about another stereotypical gender difference between men and women i.e. women are expected to be more tender than men and even for their children, men do not demonstrate any sorts of high compassion due to their conventional roles and virile attitudes.

Quote 2: A Wizard of Earthsea

\section{ST 2:}

A sister of his dead mother lived in the village. She had done what was needful for him as a baby, but she had business of her own and once he could look after himself at all she paid no more heed to him. (p. 2)

In the first book of the Earthsea Series, women have no names even though the women, who are close to the protagonist and they have significant roles in the story, do not possess a name while the main male characters are named by the author. The mother of the protagonist and his aunt are mentioned through certain descriptions that refer to their relationships with him. Even though our writer is known as a feminist author she wrote A Wizard of Earthsea, the first book of the cycle, in 1968 before feminist writing started to have an impact on literature. The feminist point of view started to take its part in literature in the late 1970s. Therefore, she did not indicate her feminist authorship in that first novel of the series.

The main purpose of feminist deconstruction is to bypass or eliminate the conventional language which praises men and men's works but underestimates women and puts them in a secondary position. However, in the first book of the series one cannot talk about any trace of a feminist perspective.

Quote 3: A Wizard of Earthsea

\section{ST 3:}

As her sister's son, he had been nothing to her, but now she looked at him with a new eye. She praised him and told him she might teach him rhymes he would like better, such as the word that makes a snail look out of its shell, or the name that calls a falcon down from the sky.

"Aye, teach me that name!" he said, being clear over the fright the goats had given him and puffed up with her praise of his cleverness.

Özgün, D. (2020). Gender discourse analysis in Ursula K. Le Guin's Earthsea series and its Turkish translation. International Journal of Linguistics, Literature and Culture, 6(4), 16-26. 
The witch said to him, "You will not ever tell that word to the other children if I teach it to you." (p. 4-5)

As in males writing or traditional writing, in which women play secondary roles and they are mostly bound to men, female characters are seldom protagonists, but they have a significant impact on main characters. Since women are not called by their names, the narrator uses some adjectives and nouns to describe them. 'witch' is one of those nouns referring to the protagonist's aunt, his mother's sister, attributes unwilling and wicked notion. Although there are other terms to define a female person who casts spells in the English language such as; magician, enchanter, sorcerer, necromancer, conjurer, occultist, charmer, etc. that do not indicate as negative meaning as a witch does, the author did not use any of them.

Quote 4: A Wizard of Earthsea and its Turkish translation

\section{ST:}

As her sister's son, he had been nothing to her, but now she looked at him with a new eye. She praised him and told him she might teach him rhymes he would like better, such as the word that makes a snail look out of its shell, or the name that calls a falcon down from the sky (p. 4-5).

TT:

Kız kardeşinin oğlu olarak ona hiçbir şey ifade etmeyen bu oğlana, artık başka bir gözle bakmaya başladl. Onu övdü ve ona daha çok hoşlanacağ tekerlemeler öğreteceğini söyledi. Bir salyangozu kabuğundan dı̧̧arı bıraktıracak bir sözcük veya bir şahini gökyüzünden çağıracak bir isim gibi (p. 12).

Even though Ursula K. Le Guin was a feminist writer in her early novels in Earthsea Cycle Series, women do not have names. Especially in her first book of the series, A Wizard of Earthsea, the author does not give names to women even if they have significant roles in the novel. As in the example which has taken from the first book, the woman who is the aunt of the protagonist in the narrative does not possess a name.

In the target text (TT) due to lack of third-person singular pronouns and possessive adjectives in the language of TT, translation of the source text (ST) cannot be equal. And also using subject pronouns is not necessary for the TT which creates another equivalent issue.

Quote 5: A Wizard of Earthsea and its Turkish translation

\section{ST:}

"Aye, teach me that name!" he said, being clear over the fright the goats had given him and puffed up with her praise of his cleverness.

The witch said to him, "You will not ever tell that word to the other children if I teach it to you" (p. 5).

TT:

"Evet, ögret bana o ismi!" dedi keçilerin uyandırdı̆̆ korkudan kurtulup, teyzesinin, ne kadar akıllı olduğu yolundaki övgüleriyle kasllmakta olan Duny.

Cadı kadın "Eğer sana öğretirsem, hiçbir zaman o sözcüğ̈̈ diğer çocuklara söylemeyeceksin," dedi.

No matter what their roles are in the stories, witches are seen as bad and cruel in every society. The narrator calls the boy's aunt as 'the witch' she also attributes a lot of good features to her such as; weather changer for the sake of villagers, healer, protector from bad spells, and so on.

In the translation, 'the witch' is translated as 'cadı kadın' to soften the discourse because the witch in the story is not bad but necessary for her village. The impact of patriarchy can easily be seen in both the ST and the TT. To avoid bias, the narrator could have used 'sorcerer', 'enchanter', or 'magician' for a female person who casts spells. However, for a male magician 'wizard', which conventionally does not refer to any sorts of wicked attributions, it is used in the story. 
Quote 6: A Wizard of Earthsea

\section{ST:}

There is a saying on Gont, Weak as woman's magic and there is another saying, Wicked as woman's magic (p. 7).

In a fictional world of Earthsea, we have an omniscient narrator and this sample is not taken from a conversation or a monologue, so it is the narrator's voice. Certain phrases humiliate women and the magic done by women. It can be said that there is an obvious misogynistic discourse in the first book. Phrases such as, "Weak as woman's magic" and "Wicked as woman's magic" show direct inferiority of women in the world level and also there are numerous of other illustrations which are full of sexist and misogynist language, therefore; the inferiority of women is in the next level as well. Furthermore, the sentence starts with "There is a saying on Gont" that suggests women are disdained by the society. Thus, downsizing women is on the social level.

\section{Quote 7: A Wizard of Earthsea}

\section{ST:}

Now the witch of Ten Alders was no black sorceress, nor did she ever meddle with the high arts or traffic with Old Powers; but being an ignorant woman among ignorant folk, she often used her crafts to foolish and dubious ends. She knew nothing of the Balance and the Pattern which the true wizard knows and serves, and which keep him from using his spells unless real need demands. She had a spell for every circumstance and was forever wearing charms. Much of her lore was mere rubbish and humbug, nor did she know the true spells from the false. She knew many curses and was better at causing sickness, perhaps, than at curing it. Like any village witch she could brew up a love-potion, but there were other, uglier brews she made to serve men's jealousy and hate. Such practices, however, she kept from her young prentice, and as far as she was able she taught him honest craft (p. 7)

In the quote above, there is a characteristic description of the witch who is the aunt of our protagonist. While at first, the narrator says she is not interested in dark magic, the following depictions not only humiliates her as an individual but all witches. The attributions she has are evil and foolish. While comparing her to a true magician the narrator does not say 'a true witch' instead says 'a true wizard' as if there cannot be a true witch. The following descriptions are like a reflection of the general view towards witches. Thus, as mentioned in the previous quotes that this village witch is helpful and necessary for her village but she mainly possesses wicked features and she is not welcomed by the villagers as well.

\section{Quote 8: A Wizard of Earthsea}

\section{ST:}

Some of the villagers fled up the ravines and hid in the forest, and some made ready to fight for their lives, and some did neither but stood about lamenting. The witch was one who fled; hiding alone in a cave up on the Kapperding Scarp and sealing the cave-mouth with spells. Duny's father the bronze-smith was one who stayed, for he would not leave his smelting-pit and forge where he had worked for fifty years (p. 10) In this band of the invading horde there were about a hundred men, which is not many; but in the village were only eighteen men and boys (p. 12)

Here in the quotes above, people of the village are under attack of some invaders from a distant land. Some villagers run away and hide, but some other villagers stay and fight for their village who are only male people stated as "eighteen men and boys". There are not many women or girls to protect the village from invaders because women need to be protected. Moreover, despite her supernatural power, the witch also runs away and hides when there is a need for her. Regardless of his age, our child wizard apprentice stays and helps the men who have the will of

Özgün, D. (2020). Gender discourse analysis in Ursula K. Le Guin's Earthsea series and its Turkish translation. International Journal of Linguistics, Literature and Culture, 6(4), 16-26. https://doi.org/10.21744/ijllc.v6n4.902 
protecting their land. There is a deliberate comparison between men and women, wizards and witches to demonstrate the general patriarchal perspective in the story.

Quote 9: A Wizard of Earthsea

\section{ST:}

Someone else was there before him, a girl, whom he knew by sight as the daughter of the old Lord of Re Albi (p. 23).

"You do not remember what I told you, that that girl's mother, the Lord's wife, is an enchantress?" (p. 28)

Another example of nameless women in the story. First, there is a girl whom we know her with her father's name. Second, the girl's mother is known with her husband's name. Whether those examples are coincidences, or the narrator deliberately avoids giving the name to female characters regardless of their roles in the story, women have no names and they are introduced with some adjectives or called by the name of their male relatives.

\section{Conclusion}

In the first book of the Earthsea Cycles, which was written in 1968, it is not possible to talk about the feminist perspective because the author used conventional non-feminist language in literature. Even though the writer of these series, Ursula K. Le Guin, is known as a feminist author, she did not write at least the first book with a feminist view. First of all, the book is full of anti-feminist examples that are given in the data analysis part. For instance, women, in the story, do not possess any names despite their significant roles. The narrator calls them by the names of their relatives such as Lady of $\mathrm{O}$, the wife of Re Albe or sometimes she describes them with some adjectives. Secondly, women of the story are highly stereotypical women as in real life. Therefore, gender roles show great similarities like women stay at home and raise children while men are out-side to earn money for their family. Thirdly, there are some word level of anti-feminist illustrations that humiliate women but praise men. For example; people with the unnatural superpower are called wizards and witches. Male ones are called wizards which attribute good characteristics while female ones are called witches that generally have negative meaning and attribution in almost all societies.

All in all, the book was written by a non-feminist language and in some cases, the language can be considered as anti-feminist or misogynist. Although the story takes place in a fictional world, it is full of real-life references in terms of gender roles. Whereas women are mainly depicted as the representation of weakness and evilness, men mostly possess good features and they represent the power and goodness. Since the study has not been finalized, the last conclusion will be made after analyzing the following selected books of the series and their Turkish translations.

\section{Conflict of interest statement}

The author declared that he has no competing interests.

Statement of authorship

The author has a responsibility for the conception and design of the study. The author has approved the final article.

\section{Acknowledgments}

The success of this study was due to many contributors who had given valuable contributions to this study. This study could not be accomplished without their contributions. Therefore, sincere gratitude goes to the head, the secretary, and all lecturers of the research center, Hac1 Bayram Veli University, Translation Department. 


\section{References}

Basil Hatim, I. M. (1990). Dsicourse and The Translator. New York/London: Longman.

Beauvoir, Simone de (1949) Le Deuxieme Sexe, Paris: Gallimard, trans, by Howard Parshley as The Second Sex, New York: Knopf, 1952.

de Beauvoir, S. (1949). Le deuxième sexe París, Gallimard. Textos seleccionados de la versión en español: El segundo sexo, 1, 47-64.

Cameron, D. (1985). Feminism and Linguistic Theory. New York: St. Martin's $P$.

Camus, C. C., Castro, C. G., \& Camus, J. T. W. (Eds.). (2017). Translation, Ideology and Gender. Cambridge Scholars Publishing.

Chamberlain, L. (1988). Gender and the Metaphorics of Translation. Signs: Journal of Women in Culture and Society, 13(3), 454-472. https://doi.org/10.1086/494428

Diaz-Diocaretz, M. (1985). Translating poetic discourse: questions of feminist strategies in Adrienne Rich (Vol. 2). John Benjamins Publishing.

Van Dijk, T. A. (Ed.). (1985). Discourse and literature (Vol. 3). John Benjamins Publishing.

Even-Zohar, I. (1990 b). Polysystem Theory, Poetics Today 11(1): 9-26.

Fairclough, N. (2003). Analysing discourse: Textual analysis for social research. Psychology Press.

Florio, J. (1603). Translators Preface; Montaignes Essayes. London.

Von Flotow, L. (1991). Feminist translation: contexts, practices and theories. TTR: traduction, terminologie, rédaction, 4(2), 69-84.

Von Flotow, L. (1991). Feminist translation: contexts, practices and theories. TTR: traduction, terminologie, rédaction, 4(2), 69-84.

Von Flotow, L. (1997). Translation and Gender: Translating in the Era of Feminism. Manchester: St. Jerome Pub.

Fowler, R. (1989). Linguistics and The Novel. London, New York: Routledge.

Georgakopoulou, A. D. (2015). The Handbook of Narrative Analysis. West Sussex: John Wiley \& Sons, Inc.

Godard, B. (1990). Theorizing Feminist Discourse/Translation. W: S. Bassnett, A. Lefevere, eds.: Translation, History. Culture. London-New York, Pinter Publishers.

Grace, A. M. (2002). A Foucault Primer Discourse, Power and the Subject. Melbourne: Melbourne University Press.

Halliday, M. A. K., \& Hasan, R. (1989). Language, context, and text: Aspects of language in a social-semiotic perspective.

Meyerhoff, M., \& Holmes, J. (2003). The handbook of language and gender. Blackwell Publishing Ltd.

House, J. (1977). A model for translation quality assessment (Vol. 88). John Benjamins Pub Co.

House, J. (2015). Translation Quality Assessment. Oxon: Routledge.

Internet: Encyclopaedia Britannica, (2018). Ursula K. Le Guin. Encyclopaedia Britannica, inc. https://www.britannica.com/biography/Ursula-K-Le-Guin

Jouve, N. W. (1991). White woman speaks with forked tongue: Criticism as autobiography (p. 193). London: Routledge.

Lazar, M. M. (2005). Feminist Critical Discourse Analysis. Singapore: Palgrave Macmillian.

Lazar, M. M. (2005). Politicizing gender in discourse: Feminist critical discourse analysis as political perspective and praxis. In Feminist critical discourse analysis (pp. 1-28). Palgrave Macmillan, London. https://doi.org/10.1057/9780230599901_1

Halliday, M. A. K., \& Hasan, R. (1989). Language, context, and text: Aspects of language in a social-semiotic perspective.

Maria Tymoczko, E. G. (2002). Translation and Power. Massachusetts: University of Massachusetts Press.

Munday, J. (2001). Introducing Translation Studies. Theories and applications, Routledge.

Munday, J. (2016). Introducing translation studies: Theories and applications. Routledge.

Paltridge, Brian. (2012). An Introduction to Discourse Analysis. 2nd ed. London: Bloomsbury.

Childs, P., \& Fowler, R. (Eds.). (2006). The Routledge dictionary of literary terms. Routledge.

Schäffner, C. (Ed.). (2002). The role of discourse analysis for translation and in translator training. Multilingual Matters.

Schäffner, C. (2004). Political discourse analysis from the point of view of translation studies. Journal of language and politics, 3(1), 117-150. https://doi.org/10.1075/jlp.3.1.09sch

Simon, S. (1996). Gender in Translation, London and New-York. Routledge, 1(996), 7.

Simon, S. (2005). Gender in Translattion. London \& New York: Routledge.

Stefan, V., \& Weckmueller, B. (1994). Shedding and Literally Dreaming. Feminist Press at CUNY.

Özgün, D. (2020). Gender discourse analysis in Ursula K. Le Guin's Earthsea series and its Turkish translation. International Journal of Linguistics, Literature and Culture, 6(4), 16-26. https://doi.org/10.21744/ijllc.v6n4.902 
Tajfel, H. E. (1978). Differentiation between social groups: Studies in the social psychology of intergroup relations. Academic Press.

Tajfel, H. (1982). Social Identity and Intergroup Relations. Cambridge: Cambridge University Press.

Toury, G. (1995). Descriptive Translation Studies-and beyond John Benjamins Publishing Company. Amsterdam/Philadelphia.

Valdeón, R. A. (2007). Ideological independence or negative mediation: BBC Mundo and CNN en Español's (translated) reporting of Madrid's terrorist attacks. In Translating and interpreting conflict (pp. 97-118). Brill Rodopi.

Von, F. L. (1997). Translation and Gender-Translating in the "Era of Feminism". 